\title{
Histomorphochemical Characterization of Harderian Gland of Goat (Capra hircus)
}

\author{
Tej Parkash*, Parveen Kumar Gahlot and Amandeep Singh \\ Department of Veterinary Anatomy, College of Veterinary Sciences, Lala Lajpat Rai University of Veterinary and Animal \\ Sciences, Hisar, Haryana, INDIA \\ "Corresponding author: T Parkash; E-mail: yadavdrtp@gmail.com
}

Received: 06 March, 2020

Revised: 18 June, 2020

Accepted: 25 July, 2020

\begin{abstract}
The present study was conducted on six young goats of local mixed breed of either sex to study the histology and histochemistry of the Harderian gland. The Harderian gland was tubulo-acinar gland, consisting of both serous and mucous secretory end pieces. The secretory units were surrounded by myoepithelial cells. Aggregates of lymphoid tissue and a patch of hyaline cartilage were noticed in the interstitial tissue. The duct system was comprised of intralobular and interlobular ducts. The histochemical studies showed a positive reaction for presence of glycogen, both acidic and neutral mucopolysaccharides and presence of weakly acidic sulfated mucosubstances, hyaluronic acid and sialomucins in the secretory units and goblet cells in the interlobular ducts.
\end{abstract}

\section{HIGHLIGHTS}

(0 Harderian gland was tubulo-acinar gland, consisting of both serous and mucous secretory end pieces.

(0 The secretory units were surrounded by myoepithelial cells.

Keywords: Histology, Histochemistry, Harderian gland, Goat

Harderian gland is a tubulo-acinar gland present on the ventro-medial aspect of the orbital cavity and its secretion support lacrimal gland in the secretion of tear and lubricated cornea and nictitating membrane of eye. The gland also plays vital in the photosensitivity, thermoregulatory behaviours and production of pheromones. The lymphoid tissue and plasma cell provides the local immunity and also play important role in maintaining the corneal health. The detailed histological studies on the Harderian gland of European bison (Nawrot et al., 2015), camel (Abou-Elmagd, 1992) sheep (Singh et al., 2019), pig (Rajkhowa et al., 2018 and Gahlot et al., 2019) and domestic fowl (Wight et al., 1971) were documenting; the goat has received little attention (Rajathi et al., 2019). Keeping in view the importance of Harderian gland, the present study describes the histological and histochemical composition of the gland in young goat and its comparison with other domestic animals.

\section{MATERIALS AND METHODS}

\section{Collection, fixation, processing and staining of tissues}

The present study was conducted on 06 young local mixed breed pigs of 6-8 months age of either sex. The heads were procured from local slaughter house immediately after decapitation; tissues were collected from Harderian gland and fixed in 10\% neutral buffered formalin solution for 48 hours. The fixed tissues were processed for routine paraffin technique of light microscopy. The paraffin sections of 5-6 $\mu$ were cut and stained by routine Harris' hematoxylin and eosin method, Gomori's method for reticular fibres, Weigert's method for elastic fibres (Luna, 1968) and Crossman's trichrome stain for collagen fibres

How to cite this article: Parkash, T., Gahlot, P.K. and Singh, A. (2020). Histomorphochemical characterization of Harderian gland of goat (Capra hircus). J. Anim. Res., 10(4): 575-578.

Source of Support: None; Conflict of Interest: None क क 
(Crossman, 1937). The histochemical characterization of mucopolysaccharides was performed by using PASAlcian blue, Alcian blue, PAS McManus' colloidal iron and Mayer's mucicarmine methods (Luna, 1968).

\section{RESULTS AND DISCUSSION}

Harderian gland was situated on the ventro-medial aspect of the orbital cavity lying under nictitating membrane at the medial canthus of eye ball. The histological studies revealed that the gland was surrounded by a thick connective tissue capsule consisting of adipose tissue, blood vessels, collagen, elastic and reticular fibers (Fig. 1). Similar findings were reported earlier in sheep (Singh et al., 2019) pig (Gahlot et al., 2019 and Rajkhowa et al., 2018) and bison (Nawrot et al., 2015) whereas; it was thin and irregular in goat (Rajathi et al., 2019). Thin connective tissue septae from the capsule penetrated into the gland and divided parenchyma it into lobes and lobules which were polygonal in shape (Fig. 2). The size of lobules varied without a definite pattern (Fig. 3). The inter-lobular septae had numerous adipocytes and blood vessels (Fig. 1). Similar findings were reported earlier in goat (Rajathi et al., 2019), bison (Nawrot et al., 2015) and pig (Gahlot et al., 2019 and Rajkhowa et al., 2018). Aggregates of lymphoid tissue and a patch of hyaline cartilage were noticed in the interstitial tissue. Plasma cells were observed in the septae and interstitial tissue as reported earlier by in sheep (Singh et al., 2019 and El Hafez et al., 2014) pig (Rajkhowa et al., 2018) and bison (Nawrot et al., 2015).

The gland was mixed consisting of tubulo-acinar units. The acini were composed of both serous and mucous acini (i.e. mixed secretory units) (Fig. 3) as observed in sheep (Singh et al., 2019) and bison (Nawrot et al., 2015). The relative proportion of serous and mucous acini was variable, depending on the position within the lobule. The mucous acini presented basophilic nuclei and had eosinophilic granular and vacuolated cytoplasm. The second types, not so numerous, were serous secretory tall conical cells. These cells had a basophilic granular cytoplasm with rounded nuclei.
This observation was in agreement with the findings in sheep (Singh et al., 2019), pig (Gahlot et al., 2019 and Rajkhowa et al., 2018), bison (Nawrot et al., 2015) and goat (Rajathi et al., 2019). The alveoli were surrounded by myoepithelial cells as reported earlier in goat (Rajathi et al., 2019), one humped camel (AbouElmagd, 1992), bison (Nawrot et al., 2015) and pig (Rajkhowa et al., 2018).

The mucous acini also showed positive reaction for glycogen by McManus' method (Fig. 4). PAS-Alcian blue method showed positive activity for both acidic and neutral mucopolysaccharides in the mucous acini with the predominance of neutral mucopolysaccharides. The findings were in agreement with findings in sheep (Singh et al., 2019), pig (Gahlot et al., 2019). The mucous acini presented the presence of weakly acidic sulfated muco-substances, hyaluronic acid and sialomucins by Alcian blue method (Fig. 5) as observed earlier in sheep (Singh et al., 2019), pig (Gahlot et al., 2019). But in contrast negative reaction for Alcian blue was observed in goat (Rajathi et al., 2019). More activity was observed towards periphery of the acini. Mayer's mucicarmine and colloidal iron (Fig. 6) showed positive activity for acidic mucopolysaccharides in the acini.

The duct system was comprised of intralobular and interlobular ducts. The intra-glandular ducts were lined by simple cuboidal epithelium whereas interglandular ducts were lined by simple cuboidal to stratified cuboidal epithelium (Fig. 2). The ducts were also surrounded by myo-epithelial cells as reported earlier in goat (Rajathi et al., 2019). The goblet cells were showing positive activity of acidic mucopolysaccharides in the inter-glandular ducts (Fig. 5). Goblet cells showed positive reaction for presence of glycogen mucous acini. Colloidal iron also showed moderate positive reaction in the goblet cells indicated the presence of acid mucopolysaccharides. Similar staining reaction were also observed in sheep (Singh et al., 2019), cattle and the American bison (Pinard et al., 2003). Whereas the ducts showed almost absence of glycogen in pig (Gahlot et al., 2019). 

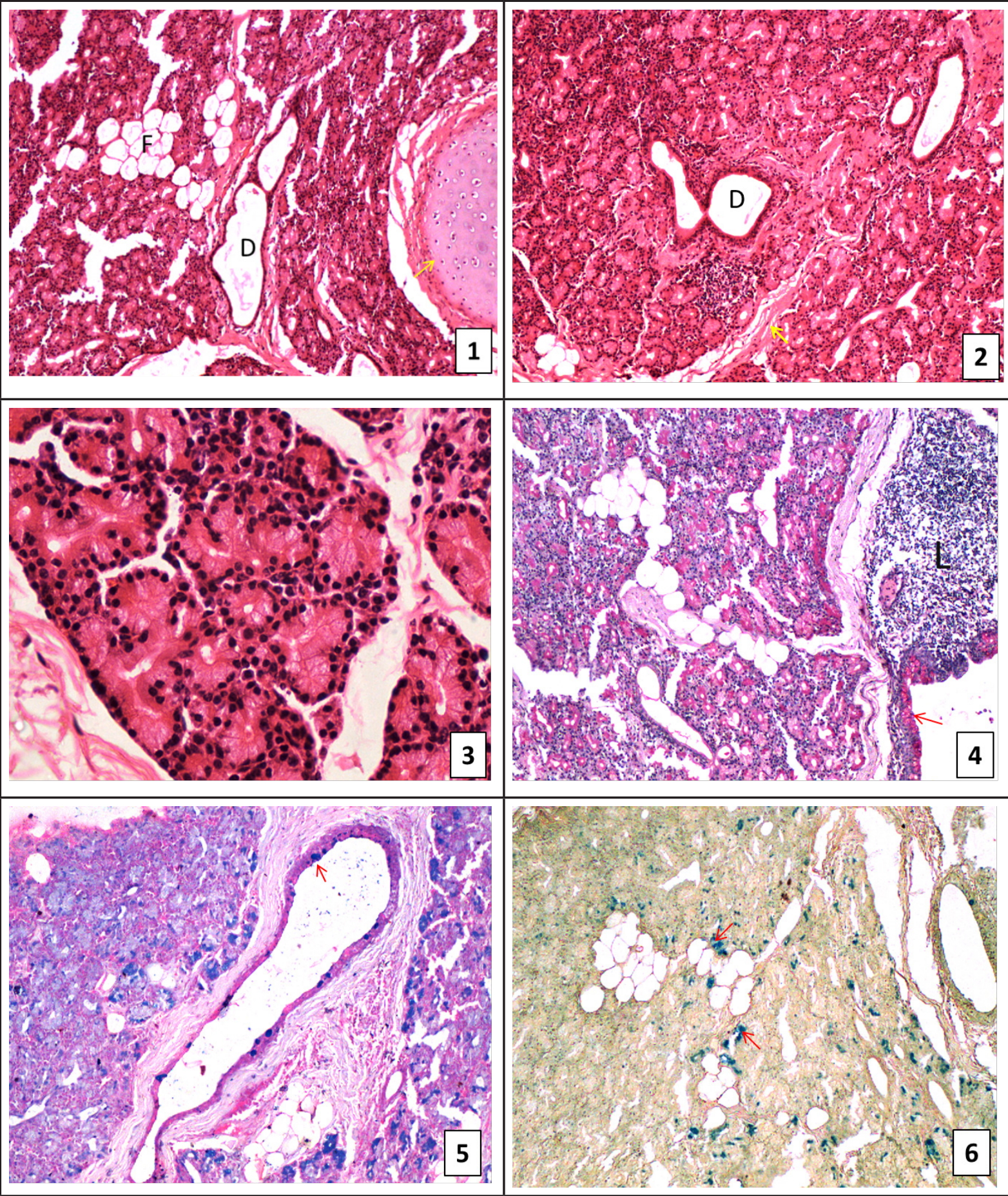

Figs. 1-6. Photomicrograph of Harderian gland of goat showing. (1) Glandular parenchyma, adipocytes (F), hyaline cartilage patch (arrow) and intralobular ducts (D) (H. \& E. × 100). (2) Glandular parenchyma along with interstitial tissue (arrow) present between adjacent secretory units contains numerous small blood vessels and interlobular ducts (D) (H. \& E. × 100). (3) Higher magnification showing glandular parenchyma comprised of mixed type of acinar cells (H. \& E. $\times 400)$. (4) Moderate positive reaction of periodic acid-Schiff (PAS) in the secretory units and goblet cells (arrow) present in ducts. Lymphoid tissue (L) was also observed (PAS $\times 100)$. (5) Acidic sulfated mucosubstances, sialomucins and hyaluronic acid in the secretory units and goblet cells (arrow) present in ductal epithelium (Alcian blue $\times 100$ ). (6) Moderate positive reaction for acid mucopolysaccharides in the secretory units (arrow) (Colloidal iron $\times 100)$ 


\section{CONCLUSION}

It may be concluded that the Harderian gland was tubuloacinar gland. The secretory units consisting of both serous and mucous secretory end pieces. Aggregates of lymphoid tissue and a patch of hyaline cartilage were noticed in the interstitial tissue. The excretory duct system was made up of intralobular and interlobular ducts. The acini showed presence of glycogen, both acidic and neutral mucopolysaccharides and weakly acidic sulfated mucosubstances, hyaluronic acid and sialomucins in the secretory units and goblet cells in the inter-glandular ducts.

\section{ACKNOWLEDGEMENTS}

We are thankful to Lala Lajpat Rai University of Veterinary and Animal Sciences (LUVAS), Hisar for providing all type of facilities to carry out the study.

\section{REFERENCES}

Abou-Elmagd A. 1992. Ultrastructural observations on myoepithelial cells and nerve terminals in the camel Harderian gland. Anat. Embryol., 185: 501-507.

Crossman, G.A. 1937. A modification of Mallory's connective tissue stain with a discussion of principles involved. Anat. Rec., 69: 33-38.

El Hafez E.A.A, Abou-Elhamd AS, Hassan AHS. 2014. Effects of Administration of Melatonin on the Harderian Gland of Sheep. J. Interdiscip. Histopathol., 2: 19-25.
Gahlot, P.K., Kumar, P., Singh, A., Parkash T. and Girgiri, I.A. 2019. Histological and histochemical studies on Harderian gland of the pig (Sus scrofa). Indian J. Vet. Anat., 31: 79-80.

Payne, A.P. 1994. The Harderian gland: A tercentennial review. J. Anat., 185: 1-49.

Luna, L.G. 1968. Manual of Histologic Staining methods of Armed Forces Institute of Pathology. 3rd edn., McGraw Hill Book Co., New York.

Nawrot, J.K., Nowaczyk, R., Harlaczuk, K.G., Szara, T. and Olbrych, K. 2015. Histology, histochemstry and fine structure of Harderian gland, lacrimal gland and superficial gland of third eyelid of the European bison. Zoologia, 32: 380-394.

Rajathi, S., Ramesh, G., Raja, K., Kannan, T.A., Sriram, P. and Hemalatha, S. 2019. Microscopic anatomy of harderian gland in goats. J. Entomol. Zool. Stud., 7: 1413-1418

Singh, A., Kumar, P., Parkash, T., Gahlot, P.K. and Girgiri, I.A. 2019. Microscopic characterization of harderian gland of sheep (Ovis aries) Haryana Vet., 58: 108-110.

Pinard, C.L., Weiss, M.L., Brightman, A.H., Fenwick, B.W. and Davidson, H.J. 2003. Normal anatomical and histochemical characteristics of the lacrimal glands in the American bison and cattle. Anat. Histol. Embryol., 32: 257-262

Wight P.A.L., Burns R.B., Rothwell B. and Mackenzie GM. 1971. The Harderian gland of the domestic fowl. Histology with reference to the genesis of plasma cells and Russell bodies. J. Anat., 100: 307-315. 